should be helpful in our review of the experience with endometrial ablation in Whipps Cross Hospital.

\section{Multinucleated stromal giant cells in ulcerative colitis}

I read with interest the paper by Dr Pitt and colleagues on colonic multinucleate giant cells in ulcerative colitis. ${ }^{1}$ Unfortunately, however, the antibody panel used by the authors failed to investigate a possible origin from factor XIIIa (FXIIIa) positive collagen-associated dendritic cells. My own observations indicate that FXIIIa dendritic cells, initially described in the dermis as socalled "dermal dendrocytes", are present in abundance throughout the whole gastrointestinal tract (figure). ${ }^{2}$ Their function and relevance to disease remain obscure but, in part, appear to include a major role in immunocompetence and antigen presentation. ${ }^{2}$ The contribution of FXIIIa cells to the pathogenesis of gastrointestinal pathology warrants extensive investigation.

Paradoxically, however, although FXIIIa antibody studies are required in Dr Pitt's case, the results may well be negative. The authors comment that the colonic giant cells resemble those in the lower female genital tract and my own observations in vulval disease indicate that such cells are FXIIIa negative. Like the authors, I suspect that their giant cells probably originate from indigenous stromal cells. Their hypothesis is, however, not proved until FXIIIa studies have been performed.

D SLATER Rotherham Hospitals NHS Trust, Moorgate Road, Rotherham S60 2UD

1 Pitt MA, Knox WF, Haboubi NY. Multinucleated stromal giant cells of the colonic lamina propria in ulcerative colitis. f Clin Pathol 1993;46:874-5.

2 Headington JT, Cerio R. Dendritic cells and the dermis: 1990. Am $\mathcal{F}$ Dermatopathol 1990; 12:217-20

Drs Pitt, Knox and Haboubi comment:

We thank Dr Slater for drawing our attention to the possibility that the multinucle- ated stromal giant cells we described in the lamina propria in ulcerative colitis may originate from FXIIIa positive dendritic cells, which he has observed to be widely distributed in the gastrointestinal tract.

In response to his suggestion we performed immunostains for FXIIIa on case 2 described in our paper and on a recent case of radiation colitis which contained similar giant cells. In both cases the multinucleated stromal giant cells were negative for FXIIIa, suggesting that these cells are not derived from dendritic cells but from other indigenous stromal cells, probably fibroblasts.

\section{Processing of uterine specimens}

The recent Association of Clinical Pathologists broadsheet, which deals with the processing of uterine specimens, advocates a more thorough sampling of the uterine corpus than most current cut up protocols. ${ }^{1}$ In most cases the latter recommended that a single histological block, including both endometrium and myometrium, should be taken from the anterior and posterior uterine wall. ${ }^{23}$ Silverberg ${ }^{4}$ recommends that an additional block should be taken from the posterior uterine serosa; although this specific recommendation is not included in many recent protocols designed for gynaecological specimens, ${ }^{1-3}$ I routinely take a block from this area as it is said to be a site of election for endometriosis. The block taken is confined to the superficial myometrium and serosa, around the posterior peritoneal reflection. It is less than $10 \mathrm{~mm}$ thick; it can thus be readily fitted into the cassette containing the block of cervix taken from the posterior lip.

I have found this an effective screening test for serosal endometriosis. In auditing 50 consecutive specimens of uterus and cervix which had been removed for a variety of benign conditions, foci of serosal endometriosis were identified in seven cases: in three cases there was associated adenomyosis; in two endometriosis was identified in the ovary; in one there was no evidence of endometriosis in either the ovaries or fallopian tubes; and in the final case the adnexae had been conserved.

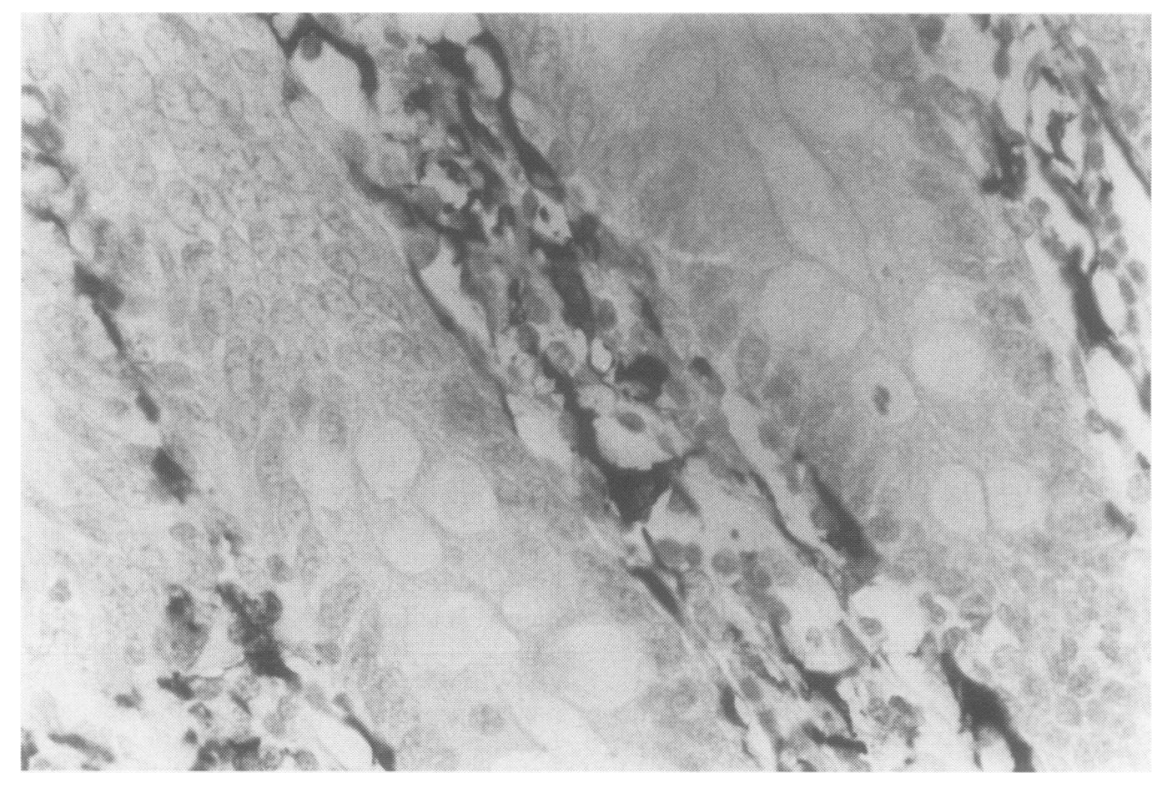

Factor XIIIa dendritic cells in normal colonic mucosa
The presence of either unexpected adenomyosis or adnexal endometriosis would normally prompt a more extensive search for endometriotic foci elsewhere in the specimen. In two of the cases above, however, the presence of endometriosis would have remained unsuspected had this screening procedure not been employed. Both patients were perimenopausal women who presented with menorrhagia. There was no macroscopic evidence of endometriosis or adenomyosis in either specimen.

Endometriosis is an important but readily treated source of morbidity in women, and may account for continued abdominal symptoms following hysterectomy. The technique described above offers the advantage of routinely examining a section from the posterior uterine peritoneum without the costs incurred in processing a separate additional histological block.

\section{MK HEATLEY Department of Histopathology, The fessop Hospital for Women, Leagreave Road,} Sheffield S3 TRL.

1 Scurry J, Patel K, Wells M. Gross examination of uterine specimens. $\mathcal{f}$ Clin Pathol 1993;46: 388-94.

2 Robboy SJ, Kraus FT, Kurman RJ. Gross description, processing and reporting of gynaecologic and obstetric specimens. In: Kurman RJ, ed. Blausteins pathology of the female genital tract. 3rd edn. Berlin: Springer Verlag, 1987:925-40.

3 Rosai J. Guidelines for handling of most common and important surgical specimens. In: mon and important surgical specimens. In 7th edn. St Louis: CV Mosby, 1989:1946.

4 Silverberg SG, ed. The uterine corpus. In: Principles and practice of surgical pathology. 2nd edn. Edinburgh: Churchill Livingstone, 1990:1729-73.

\section{Book reviews}

If you wish to order, or require further information regarding the titles reviewed here, please write or telephone the BMJ Bookshop, PO Box 295, London WC1H 9TE. Tel: 071383 6244. Fax: 0713836662 . Books are supplied post free in the UK and for British Forces Posted Overseas addresses. Overseas customers should add $15 \%$ for postage and packing. Payment can be made by cheque in sterling drawn on a UK bank, or by credit card (MasterCard, VISA, or American Express) stating card number, expiry date, and your full name.

(The price and availability are occasionally subject to revision by the Publishers.)

The Cardiovascular System. Part A: General Considerations and Congenital Malformations. 3rd edn. Vol. 1. Ed WB Robertson. (Pp 388; 310 Illustrations; $£ 85$.$) Churchill Livingstone. 1993. ISBN$ 0-443-03096-0.

This edition of Symmers' systemic pathology is being published as a separate volume for each system. In the case of the cardiovascular system there are two volumes, of which this is the first. Reviewing it is rather like trying to assess the fit of a suit with the trousers missing. 